\title{
REAL SILVER AND ITS INVESTMENT AND BUSINESS OPTIONS
}

\author{
Josef NOVOTNÝ ${ }^{4}$ Jiří POLÁCH
}

\begin{abstract}
The article deals with investment and business opportunities offered by silver. Silver is the metal used in industry and for investing at financial markets. The main problem related to this real commodity is the issue of "the undervaluation" of its investment options, if compared to gold. If considering silver as the investment option, its investment potential is significantly enhanced by its industrial usage. The aim of this paper is to highlight business and investment opportunities for both professionals and non professional investors at the commodity markets. The price growth of this investment and industrial metal can generate profits for the investors. And on the other hand, industries which cannot do without silver in their production may efficiently utilize the knowledge of setting up its price at the markets.
\end{abstract}

\section{KEY WORDS}

Investment, silver, business, commodity, industrial metal.

\section{INTRODUCTION}

Due to significant instability of current global financial markets it is not easy for the investors and entrepreneurs to make decisions on their investments. It is hard to decide the right amount and the right timing for investing one's own or others 'resources at the lowest risk and with highest yield. Investing itself and business environment are not risk-free. For the investments it is silver which could be the right option. Though silver is the investment metal and the industrial metal, surprisingly it has not been attracting the investors' attention like gold does.

The investment potential of silver is rather undervalued, if compared to gold, even despite the fact that the investment potential of silver is enhanced by its industrial use in production. Currently there exists no adequate substitute with the features corresponding to the production and physical properties of silver. The aim of the article is to draw attention to the investment and business opportunities offered by silver, the metal so widely utilized in a variety of industries. Most non professional investors associate value with gold; silver is still neglected even thought the industrial use of silver, if compared to that of gold, is more complex.

\footnotetext{
${ }^{4}$ Correspondence address: Josef Novotný, Ing., Ph.D.; 466036246 ; josef.novotny@upce.cz: Studentská 95,53002 Pardubice, University of Pardubice, Faculty of Economics and Administration; www.uni-pardubice.cz

${ }^{5}$ Correspondence address:Jiří Polách, prof., Ing., CSc.; 595228 129, jiri.polach@vsp.cz, Michálkovická 1810/181, 710

00 Ostrava, University of Entrepreneurship and Law
} 
Another fact is that there is a lack of information among the business community, even though these communities do use this metal. There are industries, e.g. electronics, which could not do without the existence of silver. Restrictions or bad timing of silver production significantly affect the price of products; substitutes are rather expensive, and in some cases silver cannot be replaced at all.

The investor who makes the decision to invest in physical silver, e.g. in the form of investment ingots, has to purchase silver from entrepreneurs operating mostly at the secondary markets. Investors are well familiar with traded commodities, on a daily basis in business or everyday life. Most frequently they come across agricultural products traded at the world commodity markets: coffee, milk, soy, orange juice. The prices of raw material at commodity markets and in business environment are influenced by to a high extend by consumers, it means "inhabitants", non investors. It is the consumer who significantly affects the amount of purchases and trade at the markets worldwide, subsequently and directly reflected in the economic results of the companies involved. Quantification of such effects is interesting, but in no way easy; the process similar to the quantification of the GDP in current globalized world.

\section{COMMODITY MARKETS}

Trading in securities in the former Czechoslovak Socialist Republic started in late 1990s. The Czech Republic and other countries of Central and Eastern Europe changed the political structure and moved from a centrally planned economy to a market economy at that time. Nowadays, a wide range of investment products, domestic and foreign companies included, aimed at professional and non professional investors. Individuals can make decision on their investments: when, how and how much to invest. Investment opportunities arise from business activities, which result from the outcomes of sophisticated financial engineering.

The main attention is currently drawn to stock and bond markets mainly, while the commodity markets seem to be rather neglected. Nesnídal and Podhajský (2007, p. 13) believe that the commodity market is one of the biggest markets in the world if considering the amount of purchased and sold commodities; the amount of purchased and sold commodities is absolutely higher than the daily amount of purchased and sold companies in the form of shares. Also land devastation, population growth and climate changes, which stand for the three aspects significantly influencing the production, extraction and return of raw materials, must be considered, because these affect the prices at the world commodity markets, too.

Polách (2012, p. 129) emphasizes the urgent need for the transformation of financial investments into real investments, because the former can produce nothing. Products are traded at the commodity markets in the paper form and the real form. However some raw materials purchased at these markets can be maintained and purchased both in paper and real forms, thus offering the advantage if compared to equity and bond markets. The real or physical form is typical for the investments in gold and silver, and where appropriate, in products made of these precious metals: jewelry, coins.

If the investor decides to invest at the commodity market via the investment instruments in the paper form, he may decide for the shares. These securities relate, for instance, to electric energy, oil. Provided the price of the electric energy grows, the profit will be generated both for the joint-stock companies and investors. And otherwise, provided the electricity price falls, both the investors and businesses will lose (and the share price will be negatively affected as well). According to Syrový and Tyl (2014, p. 112), commodity shares represent $30 \%$ of the global stock markets. Commodity markets offer more products in paper or de materialized forms: commodity funds, ETF products, etc. 
The advantage of the investment in commodities is mentioned by Shipman (2007, p. 78). While the inflation has negative impacts on stocks and bonds, commodities are affected by the inflation in a positive way. Properties of some commodities, especially those of precious metals, for instance gold, silver, make them resistant against the inflation, though we have to underline that in the real forms only.

Commodity markets offer advantages and risks. It is risky to make a decision not to conclude commercial contracts during the month the commodity has to be delivered, in order to eliminate the must to accept the commodity in its physical form. If the contract is to expire in September, the speculator will get rid of the commodity during August. And if the investor fails to leave the position in time, he will receive only the confirmation from the warehouse that the commodity was stored. Such business transactions increase the total costs (extra costs for storage), and thereby may decrease the profit, or increase the loss (Rogers, 2008). Additionally, commodity markets influence the yields, the only yield to be achieved in commodity trade is the capital yield. You cannot get any additional income, e.g. from the property renting. The issues of real estate markets are described by Squires, Heurkens (2016), Brueggeman, Fisher (1993), Zheng, Chau, Eddie (2015). And on the contrary to the stock market the commodity market cannot generate the dividend yield. The dividend policy for shares is described by Sejkora, Duspiva (2015), Jo, Pan (2009). Therefore the negatives of investments in commodities should be carefully considered by investors.

Commodity markets distinguish two large groups of traded raw materials. The first one consists of renewable commodities, represented by agricultural products especially: wheat, corn, coffee, soybeans. The second group includes non-renewable resources, represented by oil, energy, aluminum and silver. Some metals of the non-renewable resources, silver included, are used for the investment and for the production in industries.

Regardless of the market, the investor decides for, current conditions set up for individuals and businesses are generally the major aspects for investments. These may be supportive or discouraging; defined by the business environment, government, and current legislation. Purchasing power of investors and their willingness to invest accumulated funds in order to get gains indicate the transparency level of the investment environment within the current legislation context.

\subsection{INVESTMENT SILVER}

Due to significant current instability at stock and bond markets the investors' behavior has changed. Globalization and interdependence of world economies, financial markets included, are the major factors. Local crises expand to other countries as the consequence of the global development because most countries apply elements of the market economy and elements of global investing at world markets. Pavlát (2013) highlights specific elements within the globalization context.

However, investment plans can be realized even during the instability period. The real investments are the option especially during the economic and political instability, or at the times when the inflation is expected to grow. Such investments are represented by art collections, pieces of arts, properties, lands, real business and commodities; regardless of the age, education, social status, income, profession, etc, of potential investors. Investments in real activities are therefore considered a natural phenomenon, in terms of the economics, and a well founded phenomenon, in terms of the theory of cyclical economic development. Current demographic situation inspires young generation to be interested in and committed to their financial security in retirement.

Investments in real assets at commodity markets, silver mentioned, do offer the options. Each investor is the individual with his own economic background and attitude to risk. For each individual there exists the indifference curve, as described by "Markowitz", which can help set up 
the optimal investment plan just for him. The theory applies to all investors, however, as the investors are getting older, their "value pyramid" changes, and these may prefer "tangible" reasoning for the funds invested. Novotný and Polách (2014) focus on investment strategies of the seniors in the Czech Republic. Investments in real silver are promoted by current market environment. Silver is considered competitive to gold, but the features and investment potential of silver is not appreciated by beginning and non professional investors, so it remains the undervalued metal.

There are two kinds of investments in silver in its real form. The first option is to invest in silver ingots and a brick, the second option is to invest in silver coins. Investment ingots described by portal Auportál (2016) 13. 1. 2016, reached the following values: e.g. 50g - $1076 \mathrm{CZK}, 100 \mathrm{~g}-$ $1882 \mathrm{CZK}, 250 \mathrm{~g}-4370 \mathrm{CZK}, 500 \mathrm{~g}-8403 \mathrm{CZK}, 1000 \mathrm{~g}-16404 \mathrm{CZK}$. The prices are set per piece, VAT included. The ingots of 500 grams and $1000 \mathrm{~g}$ have the highest liquidity. Česká mincovna (2016) recommends the following investment coins made of silver: AmericanEaglestand 1 USD for 553 CZK, $€ 1.5$ WienerPhilharmonikerstand for CZK 524 CZK, 200 CZK silver coin Jan Pernerstand for $450 \mathrm{CZK}$. The prices are set per coin, 13. 1. 2016, VAT included. Investments in precious metals, silver included, are popular in Asia, and became a tradition in India.

The resources of silver are fewer and lesser than those of gold, which significantly enhances its investment potential. Compared to the price of gold, the silver ratio 15: 1 is recommended, but at present, the ratio reaches 60: 1. The world's reserves of silver are 5 times less than those of gold. Based on the facts stated above the price growth of silver can be expected especially due to its use by industries. Dramatic price rise within 10 to 15 years is forecasted by analysts; some experts expect 100\% increase (GoldenGate, 2016). The need to implement properly the aspect of time in the investment plans for the real silver is emphasized by Kuběnka (2015).

Investments in silver are the way to "keep and maintain the value". However, in order to maintain or increase the value, the investor needs three years for his disposal, at least. And in order to achieve a yield, the investor needs five years, at least. While cash deposited on current accounts generates little or almost no yield (related to the inflation), the value of silver in its real form increases. Sweden, and some other countries, is considering abolishing the cash money; whereas abolishing real silver is not realistic due to its use by industrial production and investments. Silver provides protection. Products made of silver (e.g. coins) are portable and affordable for small investors. But you to store silver safely.

\subsection{SILVER; ITS IMPORTANCE FOR BUSINESS}

Silver is used for the investments, but it is also a very important industrial metal. Its properties make it ideal for a wide range of applications in manufacturing companies, and at the moment there is no adequate substitute. Rejnuš (2010) and Polách (2012) emphasize the importance of investments in commodities, mainly the importance of real investments in order to support and develop business environment in services and products.

Purchase of any commodity can certainly reduce or increase the costs of businesses involved, depending on the purchase timing and related issues (e.g. current price, storage, exchange rate). Efficient use of raw materials, crucial for the commodity markets and for efficient production per production unit, silver included can lead to significant savings in production, moreover if sophisticated techniques are applied (Drábek, Polách, 2008), Decreased production costs generate higher profits, and enhance competitiveness. The importance of silver is revealed in the statistics bellow:

- Approximately $85 \%$ of world production goes into industries, the remaining portion amounting to $15 \%$ into investments. (GoldenGate, 2016). In the Czech Republic 160 tons of silver is processed 
annually, while the global production per year is approaching almost one billion ounces. Silver is used in the production of photovoltaic cells; 70 million ounces are estimated to be utilized by this industry this year. Also electronics, technical, automotive and other industries cannot do without silver. Silver is nowadays used also for the production of window glass with specific thermal isolation properties; a new technology with positive effects on the environment and the housing costs (Svět průmyslu, 2015).

Price increase of silver prices is closely linked to the consumption of goods and services accompanying the economic development of individual countries, and the standard of living of the population. Provided each adult of the world could achieve the standard of living allowing him to purchase a personal computer, a cell phone or a car, the consumption of silver would dramatically increase. Such an assumption seems to be realistic because it is based on the data on the economic growth in large countries (India, China, Brazil, and Argentina). The higher economic growth occurs, the higher consumption of silver must be expected.

\section{RESEARCH METHODS}

Analysis, synthesis, comparison, and principles of logical reasoning were used. The analysis has been used for the literature search, scientific articles and website resources, followed by the synthesis when inter relating information from available resources with the researched topic. The method of comparison was used for the comparison of the investment options for silver and gold. Investment forecasts were validated by "Commodity investment model". The model assesses whether silver is undervalued, overvalued or correctly valued.

\section{MODEL EXAMPLE OF INVESTMENT IN PHYSICAL SILVER IN THE CZECH REPUBLIC}

The value added tax (VAT) of $21 \%$ for silver means significant reduction of the achieved yield for small investors in the Czech Republic. Investors prefer gold to the silver, since gold is not the subject to VAT. Model examples of the sale and purchase of physical silver, adapted to the data obtained from the information portal Stríbro investice EU (2016) illustrate the reasons for low interest in investments in silver by small and beginning investors in the Czech Republic.

\subsection{Purchasing investment silver}

Let's assume that an individual, non-professional investor, a non VAT payer, decides to invest in physical silver with the intention to sell it within a short period. The following problem described below reflects and results from the limits set by the legislation in the Czech Republic. Business entities engaged in precious metals trade are mostly legal entities or individual entrepreneurs registered as VAT payers. These buy the investment silver as a tax-free commodity, which creates the bottleneck in trading and investing in silver. While business units may deduct the VAT in the next taxation period, individuals, non professional investors do not have such an opportunity. They have to pay the VAT at the moment of the purchase, but have to deduct the VAT when selling. The individuals have to consider the costs of the whole purchase process, for instance the trader's margin which may reach 40\% (portal Stř́bro investice EU (2016). The Table No 1 illustrates the process of investment in silver by a non-professional investor.

\section{Table No 1 Purchasing investment silver}

\begin{tabular}{|l|l|}
\hline Process of purchase & Costs in CZK \\
\hline
\end{tabular}




\begin{tabular}{|l|c|}
\hline $\begin{array}{l}\text { Value of commodity at } \\
\text { purchase }\end{array}$ & $=5000$ \\
\hline Trader's margin $10 \%$ & $0,1 * 5000=500$ \\
\hline VAT $21 \%$ & $0,21 * 5500=1155$ \\
\hline The total purchase price & $\mathbf{6 6 5 5}$ \\
\hline
\end{tabular}

(Source: own)

As defined in Table No.1 the costs may significantly limit the investments in physical silver. Extra costs, it means the costs added to the value of commodity at purchase, may stand for $25 \%$, i.e. a quarter of the purchase price. The trader's margins should also be considered; these could achieve even higher values.

\subsection{Selling the investment silver}

Problems related to the purchase of silver may even escalate if the investor decides to sell silver to another person. Let's assume that the investor decides to sell a specified amount of physical silver, he has bought, to a VAT payer. Let's use the data from the Table No 1 with the selling price of silver of 5000 Czech crowns. The model example of selling silver is illustrated in Table No 2.

\section{Table No 2 Sale of investment silver}

\begin{tabular}{|l|c|}
\hline \multicolumn{1}{|c|}{ Process of selling } & Revenue in CZK \\
\hline The price estimated by the trader & $=5000$ \\
\hline Trader's margin $10 \%$ & $0,1 * 5000=500=4500$ \\
\hline Bought from another trader (authentication) $5 \%$ & $0,05 * 4500=225=4275$ \\
\hline Other costs, loss of original documents $1 \%$ & $0,01 * 4275=42,75=4317,75$ \\
\hline Total revenue after selling & $\mathbf{4 ~ 3 1 7 , 7 5}$ \\
\hline
\end{tabular}

(Source: own)

Table No 2 shows the final revenue of 4317 CZK achieved by the non-professional individual. In order to increase the revenue some factors described in the table could be eliminated: e.g. by selling the commodity to the same trader, providing proper and correct documents. Damages caused during the process reduce the price.

If the investor decides for both above mentioned commercial transactions he will experience a significant loss. The physical commodity was bought for $6655 \mathrm{CZK}$, but sold for $4317.75 \mathrm{CZK}$, so the loss expressed in monetary units equals to $2337.25 \mathrm{CZK}$ and expressed in relative terms equals to $35.12 \%$. However, in reality the investors may achieve slightly more positive results.

\section{POSITIVE PREDICTIONS FOR INVESTMENTS IN SILVER}

The investor ready for his first investment should consider investment predictions related to his specific plans. To invest via the instruments with no or low growth potential is not the solution, especially due to potential risks. Current market conditions are favorable for the investments in physical silver, in the forms of ingots, bricks, and coins. For the investments in physical silver, the investment options by Novotný, Kruml (2016) and experts' estimates can be used. The data were provided by the company The Silver Institute (2016), which has been engaged in the silver issues 
for years. Table No 3 shows the silver price history expressed in US dollars per ounce in years 2011-2015.

Table No 3 Silver price history expressed in US dollars per ounce from 2011 to 2015

\begin{tabular}{|c|c|c|c|}
\hline Year & High & Low & Average \\
\hline 2015 & & & \\
\hline 2014 & 22,05 & 15,28 & 19,08 \\
\hline 2013 & 32,23 & 18,61 & 23,83 \\
\hline 2012 & 37,23 & 26,67 & 31,15 \\
\hline 2011 & 48,70 & 26,16 & $\mathbf{3 5 , 1 1}$ \\
\hline
\end{tabular}

(Source: The Silver Institute, 2016)

The decision must be made within the context: The first condition concerns the latest and updated information (e.g. provided by The Silver Institute). The second condition concerns the right timing of the purchase or sale, which significantly affects the investment success. The third condition is based on the assumption that silver will reach "the correct relationship" to gold, i.e. 15: 1 ratio, instead of 60:1, nowadays. Provided the conditions are met, the fourfold appreciation of the commodity value could be achieved. The investor can reach different levels of appreciation, in direct relation to the date of purchase and sale. And the final assumption is based on the highest average price.

In the model example we apply the investment option by Novotný and Kruml (2016). The investor buys one ounce of silver in US dollars at the highest average price (30.11). The purchase price of one ounce of silver is shown in Table No 3. We apply the following data for our calculations.

Option - The investor made the purchase of one ounce of silver at the highest average price of $\$$ 35.11 in 2011

$E V=P_{A} \times 4=35.11 \times 4=140.44 \$ \frac{\mathrm{E}}{\text { ounce }}$
$R b=P_{1}-P_{A}=140.44-35.11=105.33 \frac{\$}{\text { ounce }}$

$r_{b}=\frac{P_{1}-P_{A}}{P_{A}} \times 100=\frac{140.44-35.11}{35.11} \times 100=300 \%$

$\mathrm{FV}$ - expected value,

$\mathrm{Rb}$ - gross revenue in monetary units,

$\mathrm{r}_{\mathrm{b}}$ - gross revenue in percentage,

$\mathrm{P}_{\mathrm{A}}$-average price, at which the commodity was purchased,

4 - expected fourfold price increase

$\mathrm{P}_{1}-$ sale, we assume that an investor sells an ounce of silver after he reaches the fourfold appreciation.

Provided the appreciation is reached, the average annual gross revenue and time horizon must be considered. We assume that the investor reaches $300 \%$ appreciation in 15 years.

$r_{a}=\frac{r_{b}}{n}=\frac{300}{15}=20 \%$ p. $a$.

$r_{a}=$ average gross revenue in percentage per year,

$\mathrm{n}=$ number of years.

The results reveal that the investor reaches $20 \%$ of gross revenue per year during the 15 years horizon. However, if the period shortens, the investor could reach even more positive results. 
The above described option demonstrates favorable appreciation of financial funds both for the financial investor, and business entities; these can keep and maintain the goods and sell it at the moment the positive predictions are fulfilled. The appreciation can be reached in a long term horizon of ten years and more, provided the positive investment predictions made by the analysts are fulfilled. Calculations confirm the importance of the right timing of the purchase. If the investor purchases silver at the lowest price stated in the Table No 3, and the fourfold growth is reached, (while based on the highest average price), even higher revenue can be expected.

\section{COMMODITY MODELS FOR INVESTMENTS IN PHYSICAL SILVER}

The commodity model developed by Novotný (2015) for the assessment whether the commodity is undervalued or overvalued, and for defining the right moment for the purchase and sale can be used by the investors willing to invest, or the business entity willing to purchase physical silver. The model can help the investor to refine his plans on investments in physical silver.

The model based on the technical analysis is expressed in a line graph, complemented by top (upper limit) and bottom (lower limit) parts. The investment model based on numerical values can be developed (not expressed in a graph). To be able to determinate the right price of the commodity the time horizon must be defined, i.e. the section from $t_{0}$ and up to $t_{1}$.

Figure 1 describes the process of determining the right price.

The process consists of eight steps:

1. From the highest point of the examined time period, i.e. from the point $B$ the $p$ line is drawn around the latest known price $C$ - the $p$ line is defined by $B$ and $C$ points.

2. Draw $q$ line, crossing the lowest point $A$, which represents the bottom, parallel to the axis x.

3. Define point $\mathrm{D}$; as the intersection of the $p$ line and $q$ line.

4. Draw $r$ line crossing $B$ point, and parallel to the axis $\mathrm{x}$.

5. Draw $s$ line crossing $D$ point, parallel to the axis y.

6. Intersection of the lines $s$ and $r$ defines point $E$.

7. Draw $t$ line, which is defined by points $A$ and $E$.

8. An intersection of the $\mathrm{t}$ line and $\mathrm{p}$ line defines point $F$; the right price for the investor.

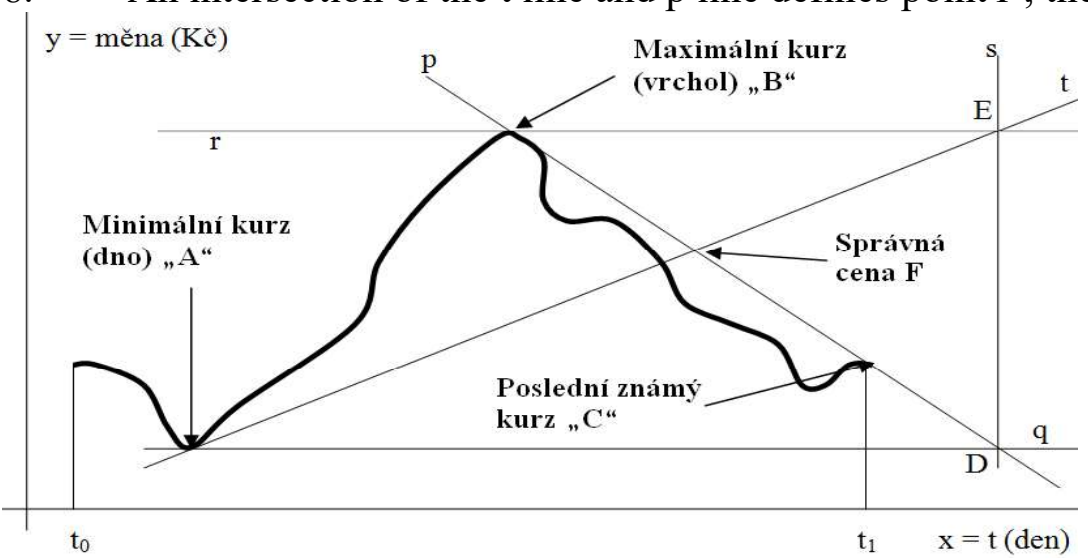

Figure No 1: Process of determining "the right" price of commodity

5.1 Mathematical formula of the investment model

Source: own adaptation (Novotný, 2014)

The model developed:

$$
y=\frac{-c_{x} b_{y}^{2}+c_{y} b_{y} b_{x}-a_{x} b_{y} c_{y}+a_{x} b_{y}^{2}-b_{x} a_{y}^{2}+c_{x} a_{y}^{2}}{2 a_{y} c_{x}-2 a_{y} b_{x}-2 b_{y} c_{x}+b_{x} b_{y}+c_{y} b_{x}-a_{x} c_{y}+a_{x} b_{y}}
$$


The data in the formula; explanation:

1. $A, B, C$ points

Point $A\left[\mathrm{a}_{\mathrm{x}} ; \mathrm{a}_{\mathrm{y}}\right]=$ minimal price of the commodity in the selected time period

Point $B\left[\mathrm{~b}_{\mathrm{x}} ; \mathrm{b}_{\mathrm{y}}\right]=$ maximal price of the commodity

Point $C\left[\mathrm{c}_{\mathrm{x}} ; \mathrm{c}_{\mathrm{y}}\right]=$ the latest known price of the commodity in the selected time period.

2. In the orthogonal coordinate system used for the calculation, the coordinate axis $\mathrm{x}$ is identified with the time period (day), y-axis stands for the currency expressed in monetary units, e.g. in Czech crowns, US dollars, Euros.

3. To simplify the calculation, the coordinate system is shifted in the direction of the $\mathrm{x}$-axis to point $A$, and the x-coordinate basis points (i.e. $A, B, C$ ) are calculated according to the unit from 0 .

From the model application we can find out whether the time for investments is the right time; provided above mentioned assumptions and conditions are met. Only certain parameters can be influenced by the investor: the length of the time horizon. Below you will find the mathematical model formulation in its general form:

$y=\frac{-c_{x} b^{2}{ }_{y}+c_{y} b_{y} b_{x}-a_{x} b_{y} c_{y}+a_{x} b^{2}{ }_{y}-b_{x} a^{2}{ }_{y}+c_{x} a^{2}{ }_{y}}{2 a_{y} c_{x}-2 a_{y} b_{x}-2 b_{y} c_{x}+b_{x} b_{y}+c_{y} b_{x}-a_{x} c_{y}+a_{x} b_{y}}$

a) Points $A, B, C$ are defined

Point $A\left[\mathrm{a}_{\mathrm{x}} ; \mathrm{a}_{\mathrm{y}}\right]=$ minimal price of silver in the selected time period.

Point $B\left[\mathrm{~b}_{\mathrm{x}} ; \mathrm{b}_{\mathrm{y}}\right]=$ maximal price of silver in the selected time period

Point $C\left[\mathrm{c}_{\mathrm{x}} ; \mathrm{c}_{\mathrm{y}}\right]=$ the last known price of silver in the selected time period.

b) $\mathrm{x}$-axis is identified with the time period (day)

c) $y$-axis is for the currency expressed in monetary units in Czech crowns,

d) to simplify the calculation the coordinate system is shifted in the direction of the $\mathrm{x}$-axis to point

$A$, and the x-coordinate basis points (i.e. $A, B, C$ ) are calculated according to the selected unit from 0 .

We assume that the investor, who invests in physical silver in Czech crowns per ounce, has chosen the time period from December 21, 2015 to January 19, 2016. In table No 4 data to calculate the right price can be found. The lowest rate of silver in Czech crowns in the examined period was 342.24 per ounce on December 30, 2015. The highest rate was 356.43 on January 07, 2016, and the last known price was 349.35 on January 19, 2016. (Kurzy, 2016)

Table No 4 Data for calculation of the right price of silver

\begin{tabular}{|c|c|l|}
\hline Points A, B, C & $\begin{array}{c}\text { Price of } \\
\text { commodity }\end{array}$ & \multicolumn{1}{c|}{ Coordinates } \\
\hline \multirow{2}{*}{ Point A } & 0 & x-coordinate of $A$ point \\
\cline { 2 - 3 } & 342,24 & y-coordinate of $A$ point \\
\hline \multirow{2}{*}{ Point B } & 5 & x-coordinate of $B$ point \\
\cline { 2 - 3 } & 356,43 & y-coordinate of $B$ point \\
\hline \multirow{2}{*}{ Point C } & 13 & x-coordinate of $C$ point \\
\cline { 2 - 3 } & 349,35 & y-coordinate of $C$ point \\
\hline
\end{tabular}

(Source: own adaptation (Novotný, 2015) 


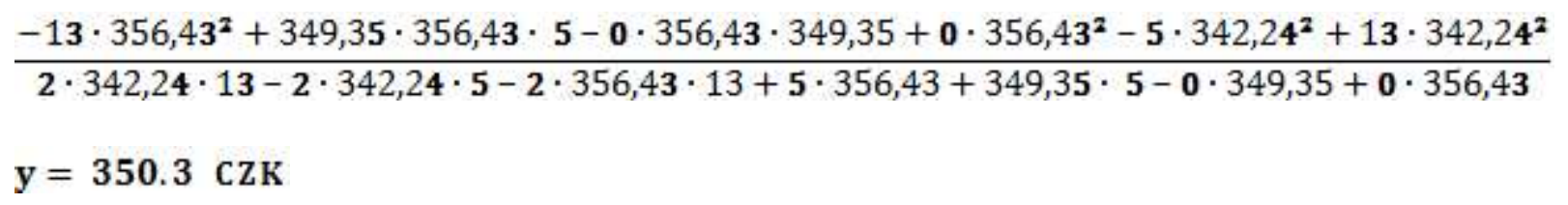

Calculations reveal that silver is the undervalued investment in the selected time period, and that silver is the commodity worth investing. The commodity has the investment potential for investors and business entities.

\subsection{DISCUSSION}

Each investment might be risky, and the fact is that we can influence some risks only. Systematic risks are hard to influence since these result from the economic situation in each economy. They are labeled as "beta" risks, and are usually segmented by industries. The tax burden ranks among the beta risks. The tax may be increased, reduced or completely abolished, depending on current political representation. Predictions by renowned experts and analysts forecasts affirm positive future for this precious and industrial metal, with the only problem related to is the time horizon; time needed for reaching the appreciation of physical silver. Both professional and non-professional investors should be patient.

Non-systematic risks can be significantly reduced by portfolios, investments groupings, which due to their characteristics (negative correlation, 27 and more.) can minimize the investor's 'losses. However, these do not allow achieving potential maximal profit. Combinations with investments in one commodity are possible, and in business practice common.

Let's go back to our topic - silver. A bottleneck related to investments in precious and industrial metals, physical silver included, is in its handling, and safe storage. The investor can store silver at his own premises, or can hire storage capacities by the external business entity: e.g. bank, but this option will definitively increase his costs.

\section{CONCLUSIONS}

Globalization processes suffering from the lack of stability at the financial markets influence and change the behavior of "the investing community". Investing in physical silver in the form of ingots, bricks and coins offers the option for the investors with the ambition to appreciate their funds. Experts on the current market situation, the commodity markets included, suggest investments in silver. The ratio of gold to silver 15: 1 is considered as the objective one; under the current conditions (new silver deposits discoveries, silver substitutes for the industry are not taken into consideration). The commodity model confirmed the hypothesis that silver is the undervalued commodity within the specific time period. Investments in physical silver are recommended for longer investment time horizons. Investments in "paper" silver in the form of stocks, securities, obligations, or derivates are considered to be short-term speculation only.

The VAT still remains the negative for the investments. VAT avoidance would be the solution. Silver is resistant to inflation, its liquidity is high; it is the enduring and still undervalued asset. Our opinion is that investments by individuals so that they could create financial funds for unexpected life situations and their retirement should be encouraged by the state. Such an approach would support the transformed philosophy of supplementary pension provisions, becoming so urgent nowadays especially due to the demographic trends in the Czech Republic. 


\section{REFERENCES}

Auportal (2016). Dostupný z www: <http://www.auportal.cz/cenik/>.

Brueggeman, B. W., Fisher, D. J. (1993) Real estate finance and investments. 9th ed. BurrRidge: Irwin, 908 p. ISBN: 0-256-08290-1

Česká mincovna (2016). Dostupný z www: <https://ceskamincovna.cz/investicni-stribro-stribrnecihly-a-slitky-397-p/>.

Drábek, J., Polách, J. Reálne a finančnéinvestovaniefiriem. 1. vyd. Zvolen: Technická Univerzita, Zlín: Univerzita Tomáše Bati, 271 s. ISBN: 978-80-228-1934-3

GoldenGate (2016). Dostupný z www: <http://www.goldengate.cz/stribro-nejlepsi-investice-tetodekady/>.

Jo, H., Pan, C. (2009). Why are firmswithentrenchedmanagers more likely to paydividends?.ReviewofAccounting and Finance, 8(1), p. 87-116.

Kuběnka, M. (2015)Finanční stabilita podniku a její indikátory. 1. vyd. Pardubice: Univerzita Pardubice, Fakulta ekonomicko-správní, 88 s. ISBN: 978-80-7395-890-9

Kurzy (2016) Dostupný Z www:

$<$ http://www.kurzy.cz/komodity/index.asp?A=5\&idk=88\&od=1.11.2015\&do=19.1.2016\&curr=CZ

$\mathrm{K} \& \mathrm{RF}=40>$.

Nesnídal, T., Podhajský, P. (2007) Obchodování na komoditních trzích: průvodce spekulanta. 2. vyd. Praha: GradaPublishing, 200 s. ISBN: 80-247-1851-0

Novotný, J. (2015) Commodityinvestment model and its signifikance forinvestors. UK: University of Oxford. EuropeanScientific Institute - International ScientificForum (ISF), pp. 68-78. ISBN: 978-608-4642-42-8

Novotný, J., Kruml, L. (2016) Theinvestmentpotentialofsilver. Mezinárodní vědecká konference - Hradecké ekonomické dny.

Novotný, J., Polách, J. Investmentoftemporarily free resourcesof Czech seniors - present and perspectives. International JournalofEntrepreneurialKnowledge (IJEK), s. 25-38. ISSN: 2336-2952

Pavlát, V. (2013) Globální finanční trhy. 1. vyd. Praha: Vysoká škola finanční a správní, 214 s. ISBN: 978-80-7408-076-0

Polách,J.,Drábek,J.,Merková,M.,Polách,J.jr.Reálné a finanční investice $1 . \quad$ Vydání Praha:,C.H.BECK,2012,280 s. ISBN 978-80-7400-436-0

Rejnuš, O. (2010) Finanční trhy. 2. vyd. Ostrava: KeyPublishing, 659 s. ISBN: 978-80-7418-080-4

Rogers, J. (2008) Žhavé komodity: jak müže kdokoliv investovat se ziskem na světových trzích. 1. vyd. Praha: GradaPublishing, 240 s. ISBN: 978-80-247-2342-6

Sejkora, F., Duspiva, P. (2015) Thepositionof management of Czech join-stockcompanies on dividend policy.Economics and Management, 18(2), p. 73-88. 
Shipman, M. (2007) Komodity: jak investovat a vydělat. 1. vyd. Brno: ComputerPress, 133 s. ISBN: 978-80-251-1866-5

Squires, G., Heurkens, E. (2016) Methods and modelsforinternationalcomparativeapproaches to realestatedevelopment. Land Use Policy, 50, p. 573-581.

Stříbro investice.EU (2016) Dostupný z www: <http://www.stribroinvestice.eu/investicni-stribro-a$\mathrm{dph} />$.

Svět průmyslu (2015) Dostupný z zww: <http://www.svetprumyslu.cz/svet-rocne-spotrebujemiliardu-unci-stribra/>.

Syrový, P., Tyl, T. (2014) Osobní finance: ř́zení financí pro každého. 2. vyd. Praha: GradaPublishing, 220 s. ISBN: 978-80-247-4832-0

The Silver Institute (2016) Dostupný z www: <https:/www.silverinstitute.org/site/silverprice/historical-prices/london-fix-price/>.

Zheng, X., Chau, K. W., Eddie, C. M. (2015)Liquidity risk and cross-sectional return in thehousing market. Habitat International, 49, p. 426-434. 